\section{ANALISIS OPTIMALISASI PERSEDIAAN DENGAN MENGGUNAKAN METODE ECONOMIC ORDER QUANTITY (EOQ)}

\author{
Hudzaifah \\ Dohar Pardomuan Marbun \\ Program Studi Manajemen Universitas \\ Pembangunan Jaya \\ hudzaifahahmad96@gmail.com
}

\begin{abstract}
Abstrak
Tujuan dari penelitian ini adalah untuk mengetahui seberapa besar pengaruh optimalisasi pemesanan persediaan yang dilakukan oleh metode $E O Q$ terhadap perusahaan Alifastore. Metode penelitian dilakukan dengan menggunakan data sekunder selama 3 tahun dari tahun 2012 sampai tahun 2014.

Hasil dari penelitian menunjukkan selisih perhitungan metode economic order quantity $(E O Q)$ dengan rata-rata penjualan perminggu sebanyak 76 unit. Sedangkan selisih perhitungan pembelian aktual perminggu dengan rata-rata penjualan perminggu sebanyak 481 unit. Total ratarata pembelian menggunakan metode $E O Q$ memiliki eror lebih kecil dibandingkan dengan rata-rata pembelian yang dilakukan oleh perusahaan, maka ada efisiensi biaya pembelian persediaan bila menggunakan metode economic order quantity $(E O Q)$.
\end{abstract}

Kata Kunci: $E O Q$, Persediaan, Optimalisasi

\section{Abstract}

The main purpose of this research is to determine how big the influence from inventory optimization order using EOQ method in Alifastore company. This research method is using secondary data for three years, from 2012 until 2014.

The result from this research shows the difference calculation using economic order quantity (EOQ) method with the average sells per week as many as 76 units. In while the difference calculation using the actual purchase with the average sells per week as many as 481 units. Total average of purchase using EOQ method has smaller errors than the average of purchase committed by the company, then there is the cost efficiency of inventory purchases when using the economic order quantity (EOQ).

Keywords: EOQ, Inventory, Optimization

\section{PENDAHULUAN}

\subsection{Latar Belakang}

Dewasa ini, perkembangan industri fesyen di Indonesia berkembang dengan pesat. Salah satu dari industri fesyen yang berkembang adalah industri busana muslim. Busana muslim merupakan segala sesuatu yang dipakai mulai dari ujung rambut 
hingga ujung kaki dan bertujuan menutup aurat bagi umat Islam. Indonesia yang memiliki mayoritas penduduk beragama Islam berpotensi untuk terus mengembangkan industri busana muslim.

Industri busana muslim di Indonesia mulai menunjukkan perkembangan yang baik sejak tahun 1990-an, namun booming baru dirasakan pada tahun 1995 hingga sekarang (Hartono, 2012). Indonesia telah memiliki industri busana muslim yang lengkap dan maju, dibandingkan dengan negara-negara yang lain. Perusahaan busana muslim di Indonesia sangat beragam jenisnya dan sangat banyak jumlahnya. Perusahaan tersebut diantaranya adalah Rabbani, El Zatta, Nibras, Tatuis, Toyusin, Mahasti, dan Azkasyah. Jenis busana muslim yang mereka produksi biasanya adalah jilbab, gamis, kaus kaki, manset, pasmina, rok, mukena, baju koko, peci, dan shawl .

Seiring dengan meningkatnya penjualan busana muslim, maka perusahaan busana muslim dituntut untuk selalu meningkatkan pelayanan dan menjamin ketersediaan barang. Dirjen Industri Kecil dan Menengah (IKM) Kementrian Perindustrian (Kemenperin), Euis Saedah, menyatakan bahwa pertumbuhan industri busana muslim di Indonesia terus meningkat setiap tahunnya, bahkan pada semester awal tahun 2012 mengalami peningkatan sebesar 8,5\%, tumbuh di atas perkembangan industri fesyen nasional yang hanya mencapai $7 \%$ per tahun. Hal tersebut membuktikan bahwa industri busana muslim memiliki peranan penting dalam pertumbuhan ekonomi Indonesia (Abdac, 2012).

Salah satu target dari perusahaan busana muslim adalah bagaimana konsumen dapat dengan mudah membeli serta mendapatkan busana muslim yang mereka butuhkan. Memenuhi kebutuhan konsumen yang sangat beragam akan sangat sulit jika tidak didukung oleh sistem distribusi dan pemasaran yang baik. Sistem distribusi serta pemasaran yang baik tentunya akan memudahkan perusahaan dalam bersaing dengan perusahaan-perusahaan lainnya serta dapat menjaring konsumen baru.

PT. Alifastore yang terletak di Pondok Aren, Kota Tangerang Selatan, adalah perusahaan yang bergerak di bidang penjualan busana muslim. Dalam operasinya, PT. Alifastore menggunakan sistem penjualan online. Para pelanggan yang tersebar di seluruh Indonesia bisa memesan busana muslim yang dijual oleh PT. Alifastore melalui website perusahaan. Website yang disediakan oleh PT. Alifastore adalah alifastore.com dan plazahijab.com sebagai anak perusahaan PT. Alifastore. Toko online Alifastore menjual beberapa merk busana muslim yang terkenal, diantaranya adalah; 
Robbani, Zoya, El Zatta, Nibras, Isykariman, Aisye, Zaqiya, Samawa, Elthof, Jilbab Tatuis, Manset safety, dan Kaos Anak Aufa.

Tujuan dibentuknya PT. Alifastore dapat digambarkan sebagaimana iklannya berikut ini: "Memberikan kepraktisan dan kenyamanan berbelanja bagi kita. Anda tidak perlu pergi ke mal ataupun toko, Anda cukup berbelanja di tempat yang paling nyaman, di rumah ataupun tempat kerja Anda, dengan harga murah dan pelayanan yang memuaskan. Tanpa perlu pergi jauh, kepanasan dan macet di jalan. Anda tinggal melihat, memilih untuk memesan barang yang anda inginkan. Setelah konfirmasi pembayaran, anda tinggal duduk manis menunggu barang dikirim dan tiba di tempat anda.” (Alifastore, 2012 )

Dalam rangka mencapai tujuan perusahaan perlu adanya pengendalian persediaan yang dapat menjamin ketersediaan yang optimal agar dapat memuaskan pelanggan. Persediaan adalah aktiva yang meliputi barang-barang milik perusahaan dengan maksud untuk dijual dalam suatu periode usaha yang normal, atau persediaan barangbarang yang masih dalam pengerjaan/proses produksi, ataupun persediaan barang baku yang menunggu penggunaannya dalam suatu proses produksi (Assauri, 1993)
Salah satu tolok ukur yang dapat digunakan dalam sistem distribusi adalah tingkat persediaan, dimana tingkat persediaan harus mampu memenuhi kebutuhan semua konsumen untuk mengurangi resiko terjadinya kehilangan penjualan. Pengambilan keputusan terhadap pengendalian persediaan barang pada jaringan distribusi akan berhasil jika ditunjang dengan penguasaan manajemen persediaan.

Menjadikan persediaan lebih efektif dan efisien sesuai dengan tujuan manajemen bukanlah hal yang mudah. Untuk mengefisienkan semua biaya pada persediaan, diperlukan optimalisasi persediaan. Menurut Winardi (1999) dalam Ali (2014) optimalisasi adalah ukuran yang menyebabkan tercapainya tujuan. Secara umum optimalisasi adalah pencarian nilai terbaik yang tersedia dari beberapa fungsi yang diberikan pada suatu konteks.

Metode yang biasa digunakan untuk mengidentifikasi kebutuhan, biaya, dan waktu pemesanan dalam persediaan adalah Economic Order Quantity (EOQ). Rangkuti (2004) dalam Sakkung dan Sinuraya, (2011) menyatakan bahwa metode $E O Q$ merupakan metode yang digunakan untuk menentukan jumlah pembelian bahan mentah pada setiap kali pesan dengan biaya yang paling rendah. Herlina (2007) dalam Sakung dan Sunariya, 
(2011) juga menyatakan bahwa metode $E O Q$ adalah metode untuk menentukan berapa jumlah pesanan yang paling ekonomis untuk satu kali pesan.

\subsection{Rumusan Masalah}

Dari permasalahan yang telah diuraikan diatas, maka perumusan masalah adalah bagaimanakah pengaruh metode EOQ terhadap optimalisasi persediaan.

\subsection{Tujuan Penelitian}

Tujuan dilakukannya penelitian ini adalah mengetahui sejauh mana pengaruh metode $E O Q$ terhadap optimalisasi persediaan.

\section{TINJAUAN TEORITIS}

\subsection{Kajian Literatur}

Kajian literatur (literature review) merupakan hal yang wajib dalam sebuah penyusunan penelitian. Menurut makna katanya, review berarti melakukan pandangan ulang terhadap setiap kelebihan dan kekurangan dari setiap pendekatan atau approach yang dilakukan oleh peneliti atau peletak teori tertentu. Oleh karena itu, perbandingan (comparison) dan pertentangan (contrast) antara berbagai macam pendekatan dalam satu subyek haruslah dimaknai untuk mencari kebenaran yang akan diacu dalam penelitian yang disusun atau untuk mencari kejelasan slot yang dapat dimasuki oleh peneliti, (Wibisono, 2013).

\subsection{Pengertian Persediaan}

Rangkuti (2007) menyatakan bahwa persediaan adalah bahan-bahan, bagian yang disediakan, dan bahan-bahan dalam proses yang terdapat dalam perusahaan untuk proses produksi, serta barang-barang jadi atau produk yang disediakan untuk memenuhi permintaan dari konsumen atau pelanggan setiap waktu.

Setiap perusahaan, apakah perusahaan itu perusahaan jasa ataupun perusahaan manufaktur, selalu memerlukan persediaan. Persediaan barang dagang merupakan elemen aktiva yang sangat aktif dalam operasi perusahaan- perusahaan dagang, karena pembelian dan penjualan barang dagangan merupakan aktivitas atau transaksi yang paling sering terjadi. Persediaan barang dagangan pada umumnya dinilai pada harga terendah antara harga perolehan dan harga pasar atau nilai yang diharapkan, Haryono (2005).

Selanjutnya menurut Assauri (1993), persediaan adalah suatu aktiva yang meliputi barang-barang milik perusahaan dengan maksud untuk dijual dalam suatu periode usaha yang normal, atau persediaan barangbarang yang masih dalam pengerjaan atau proses produksi ataupun persediaan bahan 
baku yang menunggu penggunaanya dalam suatu proses produksi.

Persediaan merupakan hal yang penting bagi sebuah perusahaan, namun hal ini tidak menjadikan perusahaan untuk memiliki persediaan yang sebanyak- banyaknya. Memiliki persediaan yang banyak memang memperkecil kemungkinan perusahaan tidak mampu memenuhi kebutuhan konsumen. Menyimpan persediaan yang banyak juga memiliki kerugian, yaitu terlalu besarnya investasi pada persediaan, kemudian meningkatnya kemungkinan barang-barang yang rusak. Perlunya pengendalian persediaan yang baik dan efisien sangatlah penting untuk mengurangi dampak buruk dari hal tersebut.

Pokok penting bagi manajemen dalam mengembangkan kebijakan persediaan adalah dapat meminimumkan total biaya yang berhubungan dengan proses produksi dari suatu perusahaan. Dua dasar keputusan persediaan yang harus dilakukan yaitu: banyaknya pesanan dalam satu waktu, dan banyaknya pesanan saat ini. Untuk mendekati dua keputusan ini ada dua cara: pesanan dengan jumlah besar dengan meminimumkan biaya pesanan, dan pesanan dalam jumlah kecil dengan meminimumkan inventory carrying cost (Thierauf dan Grosse, 1970) dalam (Nurlatifah, 2013).

\subsection{Menentukan Pesanan Persediaan}

Pesanan persediaan dapat ditentukan dengan menentukan barapa banyak persediaan yang dibutuhkan untuk menjalankan kegiatanya. Untuk menentukan persediaan yang ekonomis, diperlukan metode EOQ (Economic Order Quantity). Menurut Carter (2009) Kuantitas Pemesanan Ekonomis (Economic Order Quantity$E O Q$ ) adalah jumlah persediaan yang di pesan pada suatu waktu yang meminimalkan biaya persediaan tahunan.

\subsection{EOQ (Economic Order Quantity)}

Rangkuti (2004), menyatakan bahwa metode $E O Q$ merupakan metode yang digunakan untuk menentukan jumlah pembelian bahan mentah pada setiap kali pesan dengan biaya yang paling rendah. Herlina (2007) dalam Sakkung dan Sinuraya (2011), juga menyatakan bahwa metode EOQ adalah metode untuk menentukan berapa jumlah pesanan yang paling ekonomis untuk satu kali pesan.

Hansen dan Mowen (2001) dalam Sakkung dan Sinuraya (2011), menjelaskan hubungan EOQ sebagai metode manajemen persediaan tradisional dengan biaya persediaan yang terkait didalamnya. Dikatakan bahwa jika persediaan bahan baku yang ada dalam perusahaan merupakan bahan baku yang dibeli dari luar dan bukan diproduksi atau 
dari dalam perusahaan, maka biaya yang terkait dengan persediaan diketahui sebagai biaya pemesanan (ordering costs) dan biaya penyimpanan (carrying costs).

Metode $E O Q$ digunakan untuk menentukan kuantitas pensanan persediaan yang meminimumkan biaya langsung penyimpanan persediaan dan biaya kebalikanya (inverse cost) pemesanan persediaan, Handoko (1999). Penurunan biaya pemesanan persediaan yang dilakukan oleh metode EOQ akan menjadi optimaslisasi persediaan bagi perusahaan.

$E O Q$ bertujuan untuk meminimumkan biaya yang ditimbulkan oleh persediaan. Biaya yang penting bagi model ini adalah biaya penyimpanan, biaya pemesanan, biaya membawa atau memelihara persediaan, dan biaya penempatan persediaan. Adapun biaya lainnya seperti biaya pembelian persediaan itu sendiri, dianggap tidak relevan bagi model ini karena biaya tersebut dianggap konstan.

\subsection{Penelitian Terdahulu}

Penelitian yang dilakukan oleh Malik (2013) menyimpulkan bahwa metode EOQ memungkinkan perusahaan untuk menentukan jumlah kuantitas pesanan bahan baku yang paling ekonomis dengan jumlah permintaan dan leadtime yang konstan.
Penelitian Najich (2010) menjelaskan: "Berdasarkan perhitungan yang telah dilaksanakan, menggunakan metode $E O Q$ adalah 2-3 kali pembelian bahan baku dalam satu hari (12-8 jam perpesan) 720-1080 kali dalam satu tahun (1 tahun). Total biaya persediaan bahan baku perusahaan yang dihitung menurut EOQ lebih sedikit dibandingkan yang dikeluarkan oleh Koperasi Susu SAE Pujon Malang, maka ada penghematan biaya persediaan bahan baku bila Koperasi Susu SAE Pujon Malang menggunakan metode EOQ dalam persediaan bahan bakunya."

Penelitian yang dilakukan oleh Tjokro (2011) menyimpulkan bahwa: Persediaan adalah barang yang disimpan untuk digunakan atau dijual pada metode mendatang. Dalam hal ini metode yang sering dipakai dalam persediaan adalah metode $E O Q$, dimana $E O Q$ ini merupakan jumlah bahan baku yang harus dibeli setiap kali melakukan pembelian sehingga akan menimbulkan biaya yang paling rendah tetapi tidak akan mengakibatkan kekurangan bahan baku.

Sedangkan penelitian yang dilakukan oleh Indrayati (2007) menyatakan bahwa; Kesimpulan yang dapat diambil dari penelitian pada tugas akhir ini adalah: Total biaya persediaan bahan baku persediaan bila dihitung menurut EOQ adalah sebagai 
berikut: a) Tahun 2004 sebesar Rp855.051.790 b) Tahun 2005 sebesar Rp1.121.754.126 c) Tahun 2006 sebesar Rp1. 215.172.608 jadi total biaya persediaan yang dihitung menurut $E O Q$ lebih sedikit dibandingkan yang dikeluarkan oleh PT. Tipota Furnashing Jepara, maka ada penghematan biaya persediaan bahan baku jika PT. Tipota Furnashing Jepara menggunakan metode EOQ dalam persediaan bahan bakunya.

Penelitian yang dilakukan oleh Lestari (2012) menyatakan bahwa: Penerapan metode $E O Q$ akan meningkatkan pembelian persediaan dengan asumsu harga pokok penjualan adalah tetap maka nilai persediaan PT $X$ akan meningkat dan inventory turnover menurun. Peningkatan persediaan ini akan meningkatkan biaya persediaan usang, karena persediaan PT X memiliki masa manfaat yang terbatas sehingga penumpukan persediaan yang terlalu lama akan membuat nilai realisasi persediaan menurun.

\subsection{Kerangka Berpikir}

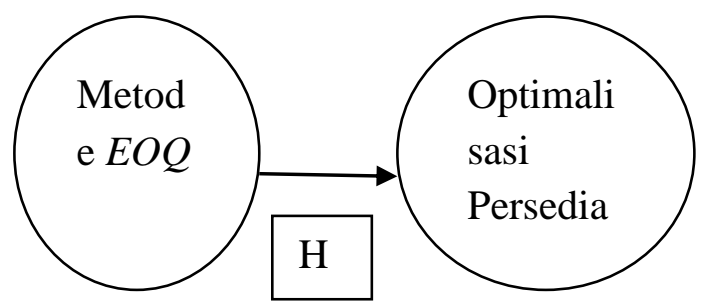

Gambar 1. Kerangka Berfikir Penelitian

\subsection{Hipotesis}

Berdasarkan konsep dan tujuan yang telah dijabarkan di atas, maka hipotesis penelitian adalah sebagai berikut: terdapat pengaruh metode EOQ untuk mengoptimalisasi persediaan.

\subsection{Metode Analisis Data}

Metode yang digunakan adalah model $E O Q$, dengan komparasi runtun waktu. Model EOQ atau Economic Order Quantity adalah model yang biasa digunakan karena mudah untuk digunakan. Dalam model ini terdapat beberapa asumsi yaitu (Heizer \& Render , 2011):

1. Permintaan telah diketahui, barang memiliki harga yang konstan atau tetap, dan memiliki keputusan yang independen terhadap barang lainnya.

2. Lead time - jeda waktu antara penempatan dan penerimaan pesanan telah diketahui dan konstan.

3. Penerimaan persediaan seketika dan lengkap. Dengan kata lain, urutan penerimaan persediaan sesuai dengan yang dipesan dan pada satu waktu.

4. Pengurangan kuantitas tidak diterima.

5. Satu-satunya variabel biaya adalah biaya pemasangan atau biaya penempatan pesanan (setup or ordering cost) dan biaya penyimpanan dari waktu ke waktu (holding or carrying cost). 
6. Kekurangan persediaan bisa dihindari jika pemesanan ditempatkan pada waktu yang tepat.

\subsection{Pengujian Hipotesis}

Data yang telah diperoleh dari sumber secara langsung, kemudian diolah sesuai dengan kebutuhan penelitian. Model $E O Q$ diuji menggunakan komparasi runtun waktu. Hasil perhitungan metode $E O Q$ dikurangi dengan jumlah rata-rata pembelian per minggu, untuk melihat tingkat eror yang dilakukan oleh metode ini. Dicari selisih perhitungan pembelian per minggu dengan penjualan perminggu. Hasil pengurangan metode $E O Q$ dengan pembelian per minggu dibandingkan dengan hasil pengurangan pembelian dan penjualan per minggu. Hasil yang didapat akan menunjukkan mana tingkatan eror yang dilakukan oleh metode $E O Q$ dan pembelian per minggu. Pengujian dilakukan pada data dari tahun 2012 sampai tahun 2014. Pengujian hipotesis bertujuan untuk mengetahui apakah hipotesis dapat diterima atau ditolak.

Menggunakan model EOQ yaitu membandingkan jumlah pemesanan optimal per minggu dengan jumlah pemesanan aktual per minggu. Jika jumlah pemesanan optimal per minggu (model EOQ) lebih besar dari jumlah pemesanan aktual maka hipotesis diterima yaitu terdapat pengaruh metode EOQ untuk mengoptimalisasi persediaan.

\section{PEMBAHASAN}

\subsection{Profil Perusahaan}

PT. Alifastore adalah perusahaan yang bergerak di distribusi busana muslim secara online. PT. Alifastore melakukan pengiriman barang pesanan ke seluruh Indonesia dengan menggunakan jasa pengiriman barang yang sudah terkenal, yaitu JNE.

\subsection{Karakteristik Data}

Pemesanan barang yang dilakukan oleh PT. Alifastore adalah secara mingguan, atau dalam 1 tahun melakukan pemesanan sebanyak 52 kali.

Data yang diambil adalah data tahun 2012 sampai tahun 2014. Data yang didapat dalam format data bulanan, sehingga harus dilakukan pengolahan khusus untuk mendapatkan data yang cocok untuk penelitian.

\subsection{Hasil analisis kuantitatif}

\begin{tabular}{|c|c|c|c|c|c|c|}
\hline \multirow[t]{2}{*}{ Tahun } & \multicolumn{2}{|l|}{2012} & \multicolumn{2}{|l|}{$\begin{array}{c}201 \\
3\end{array}$} & \multicolumn{2}{|l|}{2014} \\
\hline & $Q^{*}$ & $Q$ & $Q^{*}$ & $Q$ & $Q^{*}$ & $Q$ \\
\hline $\begin{array}{l}\text { Gamis } \\
\text { Nibras }\end{array}$ & 57 & 83 & 69 & 146 & 89 & 290 \\
\hline
\end{tabular}




\begin{tabular}{|c|c|c|c|c|c|c|}
\hline $\begin{array}{c}\text { Gamis } \\
\text { Zaqiya }\end{array}$ & 35 & 105 & 42 & 177 & 38 & 174 \\
\hline $\begin{array}{c}\text { Jilbab } \\
\text { Tatuis }\end{array}$ & 28 & 54 & 29 & 66 & 30 & 87 \\
\hline $\begin{array}{c}\text { Jilbab } \\
\text { El } \\
\text { Zatta }\end{array}$ & 56 & 160 & 60 & 220 & 68 & 327 \\
\hline
\end{tabular}

Tabel 1. Hasil Perhitungan EOQ $\left(Q^{*}\right)$ dan Pembelian Perminggu $(Q)$ (Dalam Satuan Unit)

Pada tabel di atas, dapat dilihat adanya perbedaan antara hasil perhitungan EOQ $\left(Q^{*}\right)$ dengan perhitungan hasil rata-rata pembelian per minggu $(Q)$. Tabel diatas juga menunjukkan jumlah pembelian pada setiap tahunnya.

\subsection{Hasil Pengujian}

Rangkuti (2004) dalam (Sakkung \& Sinuraya, 2011, hal. 4), menyatakan bahwa metode $E O Q$ merupakan metode yang digunakan untuk menentukan jumlah pembelian bahan mentah pada setiap kali pesan dengan biaya yang paling rendah. Menentukan jumlah pembelian merupakan usaha untuk mengurangi eror atau selisih antara pembelian yang diinventorikan dengan penjualan. Semakin kecil eror yang didapat, maka biaya yang dikeluarkan akan semakin kecil. Berkurangnya biaya yang dikeluarkan oleh perusahaan, akan meningkatkan efisiensi perusahaan tersebut. Meningkatnya efisiensi perusahaan, akan meningkatkan pula profit perusahaan, atau mengurangi biaya yang ditimbulkan oleh perusahaan.

Untuk melihat selisih antara perhitungan metode $E O Q$ dengan perhitungan rata-rata penjualan mingguan, maka dibuatlah tabel di berikut ini.

Tabel 2. Selisih Perhitungan Metode EOQ dengan Penjualan Perminggu (Dalam Satuan Unit)

\begin{tabular}{|c|c|c|c|c|}
\hline Tahun & $\begin{array}{c}\text { Gamis } \\
\text { Nibras }\end{array}$ & $\begin{array}{c}\text { Gamis } \\
\text { Zaqiya }\end{array}$ & $\begin{array}{c}\text { Jilbab } \\
\text { Tatuis }\end{array}$ & $\begin{array}{c}\text { Jilbab } \\
\text { El Zatta }\end{array}$ \\
\hline 2012 & 13 & 18 & 17 & 12 \\
\hline 2013 & 10 & 12 & 15 & 1 \\
\hline 2014 & 67 & 29 & 12 & 22 \\
\hline $\begin{array}{c}\text { Jumlah } \\
\text { Rata- } \\
\text { rata }\end{array}$ & 30 & 19,6667 & 14,666 & 11,6667 \\
\hline Jumlah & 524 & 456 & 207 & 556 \\
\hline $\begin{array}{l}\text { Rata- } \\
\text { rata }\end{array}$ & 174,66 & 152 & 69 & 185,333 \\
\hline
\end{tabular}

Rata-rata hasil perhitungan tersebut akan dibandingkan dengan hasil perhitungan ratarata pembelian yang dikurangi oleh rata-rata penjualan.

\begin{tabular}{|c|c|c|c|c|}
\hline Tahun & $\begin{array}{c}\text { Gamis } \\
\text { Nibras }\end{array}$ & $\begin{array}{c}\text { Gamis } \\
\text { Zaqiya }\end{array}$ & $\begin{array}{c}\text { Jilbab } \\
\text { Tatuis }\end{array}$ & $\begin{array}{c}\text { Jilbab El } \\
\text { Zatta }\end{array}$ \\
\hline 2012 & 88 & 105 & 54 & 160 \\
\hline 2013 & 146 & 177 & 66 & 159 \\
\hline 2014 & 290 & 174 & 87 & 237 \\
\hline
\end{tabular}


Tabel 3. Selisih Hasil Perhitungan Pembelian Perminggu dengan Penjualan Per minggu (Dalam Satuan Unit)

Tabel di atas akan dibandingkan dengan tabel sebelumnya. Dapat dilihat adanya perbedaan antara tabel 6 dengan tabel 7 . Pada Gamis Nibras, adanya selisih sebesar 144,66 unit. Hasil perhitungan EOQ, pembelian per minggu lebih rendah sebesar 144,66 unit dibandingkan dengan pembelian per minggu yang tidak menggunakan metode $E O Q$. Dengan kata lain, kemampuan untuk meminimalisir eror antara EOQ dengan pembelian sebenarnya sebesar 144,66 unit rata-rata per minggu selama tiga tahun.

Pada Gamis Zaqiya, hasil perhitungan ratarata pembelian per minggu metode EOQ sebesar 19,667, sedangkan hasil perhitungan rata-rata pembelian per minggu yang tidak menggunakan metode $E O Q$ adalah 152 unit. Maka ada selisih sebesar 132,333 unit ratarata per minggu antara perhitungan tersebut. Ini menunjukkan tingkatan eror yang terjadi jika menggunakan meode $E O Q$ lebih kecil dibandingkan dengan yang tidak menggunakan metode ini.

Pada Jilbab Tatuis, metode EOQ lebih rendah sebanyak 54,34 unit rata-rata perminggu dibandingkan dengan pembeliaan perminggu konvensional. Ratarata pembelian perminggu metode EOQ sebesar 14,666 unit, sedangkan rata-rata pembelian perminggu yang tidak menggunakan metode $E O Q$ sebesar 69 unit. Selisih ini menunjukkan kemampuan metode EOQ mengurangi eror dalam pembelian.

Pada Jilbab El Zatta, perhitungan pembelian perminggu metode EOQ sebanyak 11,666 unit, dan perhitungan pembelian perminggu konvensional sebesar 185,333 unit. Pada Jilbab El Zatta, selisih antara perhitngan $E O Q$ dengan pembelian konvensional sebesar 173,67 unit rata-rata perminggu.

Untuk semua merk gamis dan jilbab, perhitungan metode EOQ memiliki eror yang lebih kecil dibandingkan dengan perhitungan yang tidak menggunakan metode EOQ. Pada perhitungan di atas, menunjukan bahwa metode $E O Q$ mampu mengurangi eror pada pembelian barang. Pengurangan eror pada pembelian akan mengurangi biaya yang tidak perlu. Berkurangnya biaya pembelian akan meningkatkan efisiensi perusahaan.

\section{KESIMPULAN DAN SARAN}

Dari hasil penelitian dan pembahasan pada bab-bab sebelumnya, dapat diambil kesimpulan sebagai berikut:

1. Pelaksanaan prosedur permintaan, pemesanan, dan penerimaan PT 
Alifastore sudah baik, karena sudah mengikuti standar yang telah ditetapkan oleh perusahaan.

2. Persediaan barang pada PT Alifastore pada tahun 2012 sampai tahun 2014 selalu mengalami kelebihan persediaan.

3. Pembelian pada keempat produk menggunakan metode EOQ dapat mengurangi eror.

4. Perhitungan metode $E O Q$ pada Gamis Nibras mampu mengurangi eror sebanyak 144,66 unit rata-rata pembelian per minggu dalam tiga tahun. Penggunaan metode EOQ bisa meningkatkan efisiensi perusahaan karena mengurangi jumlah eror dari pembelian per minggu terhadap penjualan perminggu.

5. Pembelian rata-rata Gamis Zaqiya pada 3 tahun berturut-turut (2012-2014) membuat perusahaan tidak efisien. Eror rata-rata pembelian adalah 132,33 unit perpembelian perminggu lebih banyak dibandingkan dengan perhitungan metode $E O Q$.

6. Pada Jilbab merk Tatuis, jika menggunakan perhitungan metode $E O Q$ memiliki jumlah eror yang lebih rendah sebanyak 54,34 unit rata-rata pembelian per minggu dibandigkan dengan rata-rata pembelian per minggu aktual. Pada perhitungan metode EOQ, eror yang dikurangi terjadi dalam tiga tahun, yaitu dari tahun 2012 sampai tahun 2014.
7. Pembelian rata-rata per minggu aktual pada Jilbab El Zatta sebanyak 185, 33 unit. Jumlah tersebut jauh diatas perhitungan yang menggunakan metode $E O Q$, yaitu sebanyak 11,667 unit ratarata pembelian per minggu. Terjadi selisih sebesar 173,67 unit rata-rata pembelian per minggu dalam 3 tahun.

8. Penelitian ini membuktikan bahwa penelitian-penelitian terdahulu yang membuktikan bahwa $E O Q$ meningkatkan efisiensi perusahaan adalah benar. Seperti yang di ungkapkan oleh Freddy Rangkuti (2004), bahwa metode $E O Q$ merupakan metode yang digunakan untuk menentukan jumlah pembelian bahan mentah pada setiap kali pesan dengan biaya yang paling rendah.

9. Penelitian ini sesuai dengan penelitian yang dilakukan oleh Malik (2013). Pada penelitain ini menyimpulkan bahwa metode $E O Q$ memungkinkan perusahaan untuk menentukan jumlah kuantitas pesanan bahan baku yang paling ekonomis dengan jumlah permintaan dan leadtime yang konstan. Maka metode $E O Q$ tidak hanya berlaku bagi PT Alifastore, namun juga berlaku bagi perusahaan lain, walaupun itu bukan perusahaan dagang. 


\section{Saran}

Berdasarkan kesimpulan diatas, maka pemberian saran kepada perusahaan agar dapat digunakan sebagai bahan pertimbangan untuk melakukan peninjauan kembali terhadap kebijakan persediaan barang yang selama ini telah dilakukan oleh perusahaan, ialah;

1. Sebaiknya perusahaan menerapkan metode $E O Q$ yang telah terbukti mampu mengurangi eror pada rata-rata pembelian per minggu, sehingga menciptakan biaya pembelian yang lebih rendah serta menigkatkan efisiensi secara signifikan.

2. Untuk dapat lebih melihat efisiensi dari metode $E O Q$, maka ada beberapa hal yang perlu dilakukan, yaitu:

a. Data yang didapatkan memiliki rentang waktu yang lebih panjang.

b. Jumlah barang dalam sekali pesan lebih banyak.

c. Interval pemesanan lebih sering.

d. Varian produk lebih beragam.

Keempat hal ini diperlukan untuk melihat seberapa stabil EOQ dalam mengurangi eror.

\section{Daftar Pustaka}

1. Abdac, Y. (2012). Industri Busana Muslim di Indonesia Berlari Meninggalkan Busana Konvensional. http://www.pakarkonveksi.info/2012/08/ industri-busana-muslim-diindonesia.html

2. Ali, M. A. (2014). Analisis Optimalisasi Pelayanan Konsumen. eJournal Ilmu Administrasi Bisnis.

3. Alifastore. (2012). Profil Alifastore. http://alifastore.com/profil/

4. Assauri, S. (1993). Manajemen Produksi. Lembaga Penerbit Fakultas Ekonomi Universitas Indonesia.

5. Azwar. (1987). Metodologi Penelitian. PT. Binarupa Aksara.

6. Hartono. (2012). Kemenperin Gelar Pameran Produk Busana Muslim. http://www.kemenperin.go.id/artikel/396 3/Kemenperin-Gelar-Pameran-ProdukBusana-Muslim

7. Heizer, J., \& Render , B. (2011). Operations Management. Pearson.

8. Nurlatifah, S. Z. (2013). Beberapa Bentuk Model Inventori Deterministik. Skripsi.

9. Rangkuti, F. (2004). Analisis SWOT Membedah Kasus Bisnis. PT. Gramedia Utama.

10. Rangkuti, F. (2007). Manajemen Persediaan. PT. Raja Grafindo Persada. 